Annals of Warsaw University of Life Sciences - SGGW

Land Reclamation No 49 (1), 2017: 29-41

(Ann. Warsaw Univ. Life Sci. - SGGW, Land Reclam. 49 (1), 2017)

\title{
Roughness parameters as the elements of surface condition and deformation assessment based on the results of TLS scanning
}

\author{
MARIA E. KOWALSKA, JANINA ZACZEK-PEPLINSKA \\ Faculty of Geodesy and Cartography, Warsaw University of Technology
}

\begin{abstract}
Roughness parameters as the elements of surface condition and deformation assessment based on the results of TLS scanning. Roughness is the attribute of a surface that can be defined as a collection of small surface unevennesses that can be identified optically or detected mechanically which do not result from the surface's shape and their size depends on a material type as well as on undergone processing. The most often utilised roughness parameters are: $R a$ - mean distance value of the points on the observed profile from the average line on the sampling length, and $R z$ - difference between arithmetic mean height of the five highest peaks and arithmetic mean depth of the five deepest valleys regarding to the average line on the length of the measured fragment. In practice, roughness parameters are most often defined for surface elements that require relevant manufacturing or processing through grinding, founding or polishing in order to provide the expected surface roughness. To measure those parameters for the produced elements profilometers are used. In this paper the authors present an alternative approach of determining and utilising such parameters. Instead of the utilising methods based on sampling length measurement, roughness parameters are determined on the basis of point clouds, that represent a surface of rough concrete, obtained through terrestrial laser scanning. The authors suggest using the surface roughness parameter data acquired in this way as a supplementary data in the condition assessment (erosion rate) of surfaces being a part of engineering constructions made of concrete.
\end{abstract}

Key words: terrestrial laser scanning, roughness, deformations, displacements in engineering objects

\section{INTRODUCTION}

Concrete surfaces, due to their nature, are affected by surface erosion caused by the influence of weather conditions. The authors of the paper suggest using data from terrestrial laser scanning (TLS) in order to define roughness parameters that will serve as a complementary element in the condition assessment of surfaces of engineering constructions. Based on the determined parameters it is possible to extrapolate the necessity to introduce additional protective measures by cleaning, covering the surface with protective agent or grinding and filling of cavities.

Terrestrial laser scanning is a measurement method that allows the registration of millions of points representing surveyed surface. The instrument emits a laser beam that makes it possible to determine the distance from the surveyed surface. The XYZ coordinates and the intensity value of the reflected beam for 
each point are obtained as a result of scan. This method enables a contactless measurement of the surveyed object's surface. Owing to the point clouds registered during the scan it is possible to create quasi-continuous point models of the surface. A number of geometric analyses as well as detailed analytical and computational considerations can be carried out using those models as a base. Identification of roughness parameters for selected fragments of a surface can serve as an example of an analysis based on the data from terrestrial laser scanning.

\section{Roughness and its parameters}

Roughness is a surface attribute, that can be defined as a collection of small surface unevenness's, which do not result from the surface's shape. Small surface unevennesses can be identified optically or detected mechanically. Their size depends on the material type and undergone processing. Therefore roughness is an optically noticeable or mechanically detectable unevenness of a surface.
Numerous parameters and norms used to create qualitative and quantitative descriptions of surface roughness were defined in subject literature and norms. However, two of them are most frequently used ( $R a$ and $R z$ ), among which $R a$ plays the leading role (Dobrzyński 1977, Skupnik 2013).

Mean arithmetic deviation of surface roughness profile forming the average line $(R a)$, which is the average value of distance between points $y_{1}, y_{2}, \ldots y_{n}$ on the observed profile from the average line on the sampling length (Fig. 1).

$$
R a=\frac{1}{n} \sum_{i=1}^{i=n}\left|y_{i}\right|
$$

where:

$n$ - number of points,

$y_{i}-$ distance between point and observed profile.

Difference between arithmetic mean height of the five highest peaks and arithmetic mean depth of the five deepest valleys $(R z)$, regarding average line on the length of the measured distance

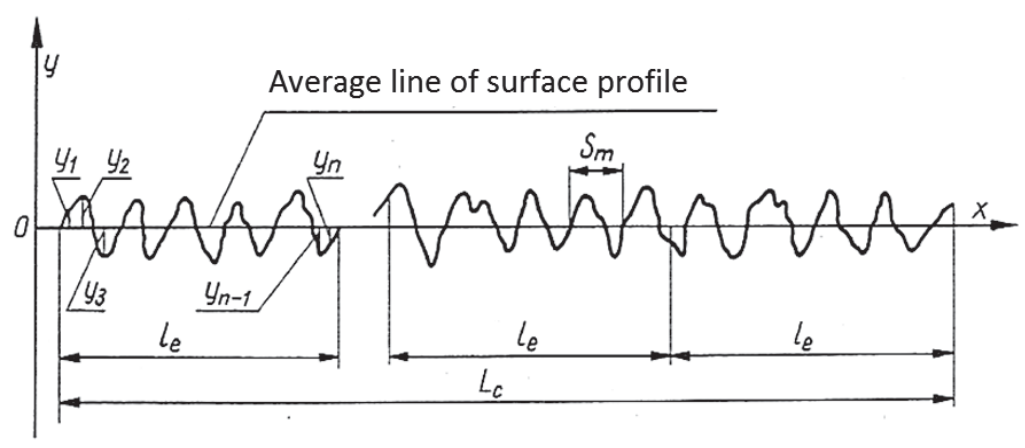

FIGURE 1. Diagram defining $R a$ roughness parameter 


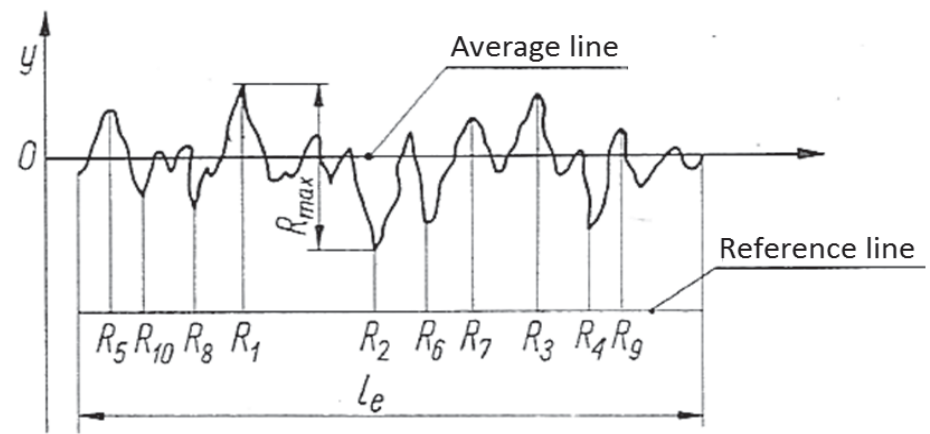

FIGURE 2. Diagram defining $R z$ roughness parameter (the reference line can take the form of the profile average line)

(roughness based on 10 points on the profile) - Figure 2.

In the above definitions the profile average line is a line in the shape of the nominal profile (designed) that divides the profile in such a way that on the distance of the sampling length $\left(L_{e}\right)$ the sum of the squared distances of the points belonging to the observed profile is the smallest.
The issue of roughness is directly connected to materials engineering, thus in practice roughness parameters are most often defined for surface elements that require relevant manufacturing or processing through grinding, founding or polishing in order to provide the expected surface roughness. Profilometers, which make it possible to measure the peaks and valleys along the surveyed

$$
R z=\frac{W_{1}+W_{2}+W_{3}+W_{4}+W_{5}}{5}+\frac{\left|D_{1}+D_{2}+D_{3}+D_{4}+D_{5}\right|}{5}=\frac{1}{5}\left(\sum_{1}^{5}\left|y_{p i}\right|+\sum_{1}^{5}\left|y_{v i}\right|\right.
$$

where:

$W_{1}, W_{2}, W_{3}, W_{4}, W_{5}$ - distances between

the five highest peaks and reference line,

$D_{1}, D_{2}, D_{3}, D_{4}, D_{5}-$ distances between the five deepest valleys and refer ence line,

$y_{p i}$ - distance between the highest peaks and observed profile,

$y_{v i}$ - distance between the deepest valleys and observed profile. profile, are used to measure those parameters. This measurement is made with the accuracy equal to a single micrometre. However, in the case of surfaces belonging to massive concrete structure carrying out this kind of measurements is impossible. Character of the deformation and irregularities on the surface of the concrete is completely different then on surfaces made of steel or synthetic materials. On technical grounds of the way the casting of concrete, marks on the 
surface remaining after the formwork and shuttering process, and also observed fouling vegetation changes diagnosed roughness parameters are in centimetres rather than millimetres. For example we have to diagnose slits with a depth of $1-2 \mathrm{~cm}$ and a width of $0.5-2 \mathrm{~cm}$, which occasionally come to $5-10 \mathrm{~cm}$. The accuracy of point clouds obtained from terrestrial laser scanning is suitable for measuring the components of this size. Due to this fact application of data obtained through terrestrial laser scanning was suggested.

\section{MATERIAL AND METHODS}

In order to determine roughness parameters for a concrete surface it is essential to determine the profile average line against which point distances will be calculated. Surfaces for which roughness parameters can be determined may be vertical or inclined. Due to their orientation in space two different approaches can be used, which are presented in the further part of the article.

\section{Determining roughness parameters for vertically oriented surfaces}

Due to the orientation of vertical surfaces the regression line fit into a point cloud projected onto a horizontal plane can serve as the average line. This simplification is possible because one of the surface's edges is parallel to the $\mathrm{Z}$ axis.

Linear regression, which minimizes point drifts from the line running along the $X$ and $Y$ axes, is the most often used concept in numerical studies and analyses of sets of two-dimensional points. Orthogonal regression is distinguished from the simple linear regression by the fact, that the parameters of the approximation line are computed on the basis of a minimization of the sum of the squared distances of the points $(x, y)$ from the sought regression line. Due to that fact, it fulfils the previously mentioned criteria of the average line. By determining the line of orthogonal regression two perpendicular lines are obtained that define the minimum and maximum of the sum of the squared distances (Cramér 1999). The proceedings leading to determination of the parameters for the orthogonal regression line are presented below (Zaczek-Peplinska 2015).

$$
x \cos \beta+y \sin \beta-p=0
$$

$x, y$ - points coordinates,

$\beta-$ the angle of slope to the axis $0 \mathrm{X}$,

$p$ - distance between the line and the centre of the coordinate system,

$d$ - directed distance from a point to a line of a normal equation,

$n-$ number of points.

$$
\begin{gathered}
d=|x \cos \beta+y \sin \beta-p| \\
E=\sum_{i=1}^{n} d_{i}^{2}=\sum_{i=1}^{n}\left(x_{i} \cos \beta+y_{i} \sin \beta-p\right)^{2} \\
\frac{\partial E}{\partial p}=-2 \sum_{i=1}^{n}\left(x_{i} \cos \beta+y_{i} \sin \beta-p\right)=0
\end{gathered}
$$


so

$$
p=\frac{1}{n} \sum_{i=1}^{n}\left(x_{i} \cos \beta+y_{i} \sin \beta\right)=\cos \beta \frac{1}{n} \sum_{i=1}^{n} x_{i}+\sin \beta \frac{1}{n} \sum_{i=1}^{n} y_{i}=\bar{x} \cos \beta+\bar{y} \sin \beta
$$

Elimination of the $p$ parameter from the objective function results in:

incidence angles of the scanned surface. According to the characteristics of the scanner - for the distance up to $50 \mathrm{~m}$

$$
\frac{\partial E}{\partial \beta}=-\sin 2 \beta \sum_{i=1}^{n}\left(X_{i}^{2}-Y_{i}^{2}\right)+2 \cos 2 \beta \sum_{i=1}^{n} X_{i} Y_{i}=0
$$

where:

$X_{\mathrm{i}}, Y_{\mathrm{i}}$ - relative coordinates to the centre of gravity of the set of points.

Thus $\tan 2 \beta=T \frac{2 a}{b}$

where $a=\sum_{i=1}^{n} X_{i} Y_{i} ; b=\sum_{i=1}^{n}\left(X_{i}^{2}-Y_{i}^{2}\right)$

finally $\beta_{k}=\frac{1}{2} \tan ^{-1} T+\frac{\pi}{2} k$ for $k=0.1$

because

$\cos 2 \beta=\frac{2 a}{ \pm \sqrt{4 a^{2}+b^{2}}} \sin 2 \beta=\frac{b}{ \pm \sqrt{4 a^{2}+b^{2}}}$

is $E=\sum_{i=1}^{n} \frac{X_{i}^{2}+Y_{i}^{2}}{2} \pm \sqrt{4 a^{2}+b^{2}}$

In order to assess the applicability of roughness parameters in evaluation of concrete surface condition experimentally a scanned cubic hydrotechnical concrete sample sized $10 \times 10 \times 10 \mathrm{~cm}$ was used (Fig. 3). The block was scanned from the distance of $20 \mathrm{~m}$ by using $\mathrm{Z}+\mathrm{F}$ Imager 5006h scanner operating in various operational modes and with various the linearity error is less than or equal to $1 \mathrm{~mm}$. Due to the measurement technology and the size of the object the roughness parameters were determined in $\mathrm{mm}$ but not in micrometers $(1 \mu \mathrm{m}=0.001 \mathrm{~mm})$

a

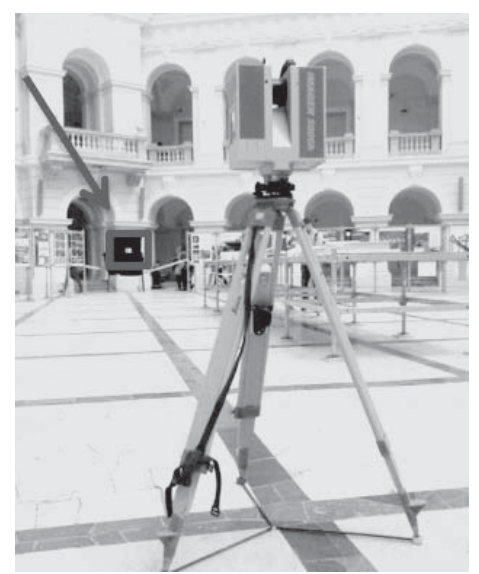

b

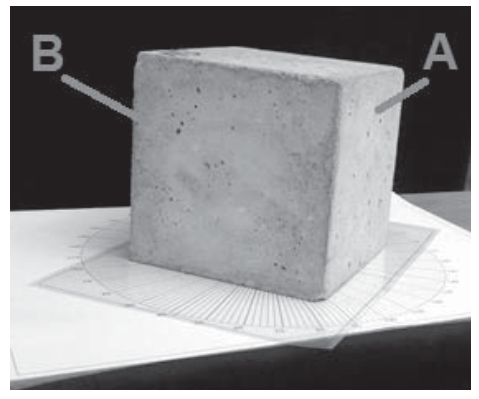

FIGURE 3. a - view of the test field, $\mathrm{b}$ - cubic concrete sample with marked A and B surfaces Source: Kowalska and Zaczek-Peplinska 2015. 
as it is the case when evaluating surfaces for processing quality purposes.

Determined roughness parameters are dependent on the selected density obtained through measurement of the point cloud. Table 1 presents values of the obtained resolution depending on the scanners operational mode with scanning distance set to $20 \mathrm{~m}$. Table 2 summarises the values of $R a$ and $R z$ parameters for

TABLE 1. Dependence of a scan resolution in the $\mathrm{Z}+\mathrm{F}$ Imager 5006h scanner's operational mode - distance between neighbouring points (beam's angle of incidence $0^{\circ}, D$ - distance from the scanner)

\begin{tabular}{|c|c|c|c|}
\hline \multirow{2}{*}{$D(\mathrm{~m})$} & \multicolumn{3}{|c|}{ Resolution } \\
\cline { 2 - 4 } & $\begin{array}{c}\text { "ultra } \\
\text { high" }\end{array}$ & "high" & "middle" \\
\cline { 2 - 4 } & \multicolumn{3}{|c|}{$\mathrm{mm}$} \\
\hline 10 & 1.6 & 6.3 & 12.6 \\
\hline 20 & 3.2 & 12.6 & 25.2 \\
\hline
\end{tabular}

Source: Kowalska and Zaczek-Peplinska 2015.

TABLE 2. Summary of $R a$ and $R z$ values for surface A of the concrete sample (resolution $\mathrm{m}$ - "middle", h - "high", u - "ultra high")

\begin{tabular}{|c|c|c|r|r|}
\hline $\begin{array}{c}\text { Beam's } \\
\text { angle of } \\
\text { incidence }\left({ }^{\circ}\right)\end{array}$ & $\begin{array}{c}\text { Reso- } \\
\text { lution }\end{array}$ & $\begin{array}{c}R a \\
(\mathrm{~mm})\end{array}$ & $\begin{array}{c}R z \\
(\mathrm{~mm})\end{array}$ & $\begin{array}{c}\text { Number } \\
\text { of points }\end{array}$ \\
\hline \multirow{3}{*}{34} & $\mathrm{~m}$ & 3.39 & 10.47 & 21 \\
\cline { 2 - 5 } & $\mathrm{h}$ & 1.08 & 7.44 & 97 \\
\cline { 2 - 5 } & $\mathrm{u}$ & 1.07 & 15.94 & 1523 \\
\hline \multirow{4}{*}{40} & $\mathrm{~m}$ & 5.36 & 20.61 & 28 \\
\cline { 2 - 5 } & $\mathrm{h}$ & 1.04 & 5.96 & 89 \\
\cline { 2 - 5 } & $\mathrm{u}$ & 1.06 & 24.25 & 1405 \\
\hline \multirow{4}{*}{44} & $\mathrm{~m}$ & 2.79 & 7.95 & 18 \\
\cline { 2 - 5 } & $\mathrm{h}$ & 0.69 & 3.46 & 74 \\
\cline { 2 - 5 } & $\mathrm{u}$ & 1.18 & 14.34 & 1297 \\
\hline \multirow{3}{*}{60} & $\mathrm{~m}$ & 3.55 & 7.14 & 12 \\
\cline { 2 - 5 } & $\mathrm{h}$ & 1.26 & 5.29 & 59 \\
\cline { 2 - 5 } & $\mathrm{u}$ & 0.97 & 7.97 & 943 \\
\hline
\end{tabular}

Source: Kowalska and Zaczek-Peplinska 2015. surface A of the concrete sample using different operational modes (resolution $\mathrm{m}$ -“middle", h - "high", u - "ultra high").

In order to provide a better visualization of the results presented in the table the said results were further presented in a graphical form. Figure 4 clearly illustrates that the obtained value of roughness parameter depends on the scan resolution. The roughness parameter value significantly deviates for the "middle" resolution setting. This is caused by an imprecise capture of the surface on the point cloud. The distance between registered points is big enough to cause disruption in actual roughness. This effect is not present when resolution is set to "high" and "ultra high" as more points are being recorded. For "high" and "ultra high" resolutions and angles of incidence at $34^{\circ}$ and $40^{\circ}$ the $R a$ parameter is equal at $0.02 \mathrm{~mm}$, whereas for angles of incidence at $44^{\circ}$ and $60^{\circ}$ the discrepancy reaches 0.49 and $0.29 \mathrm{~mm}$ respectively (Table 2). The $R z$ parameter variability takes on a completely different character than $R a$ variability as presented in Figure 5. Values of $R z$ for an identical sample scanned using different angles of incidence are most convergent when the resolution is set to "high". However, it cannot be treated as reliable. In order to verify this assumption, the standard deviation values for the five deepest and the five highest points used to determine the parameter and the whole sample were compared. The obtained results are 


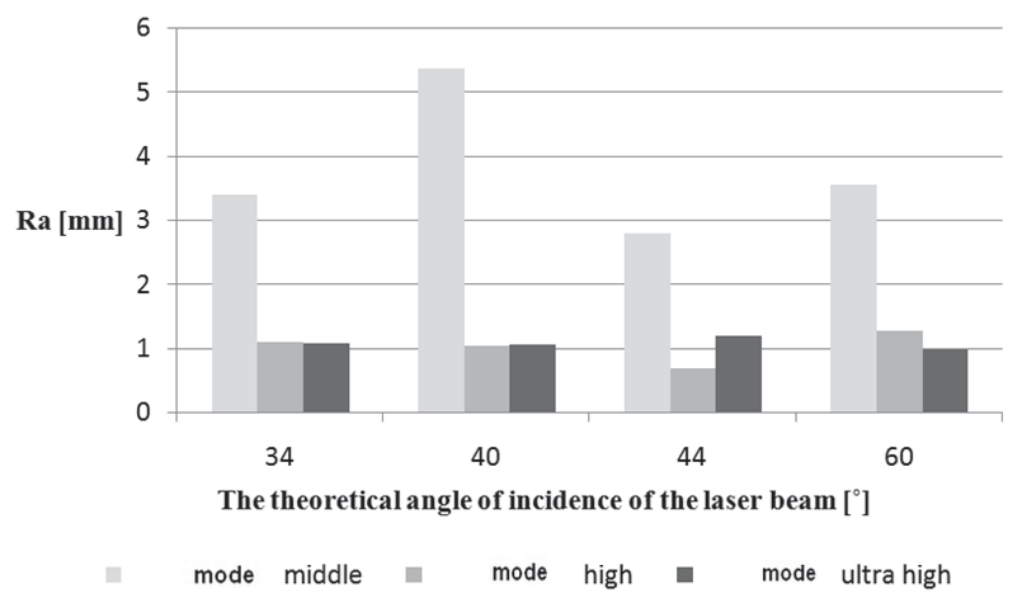

FIGURE 4. Graph presenting Ra parameter values for surface A of the concrete sample

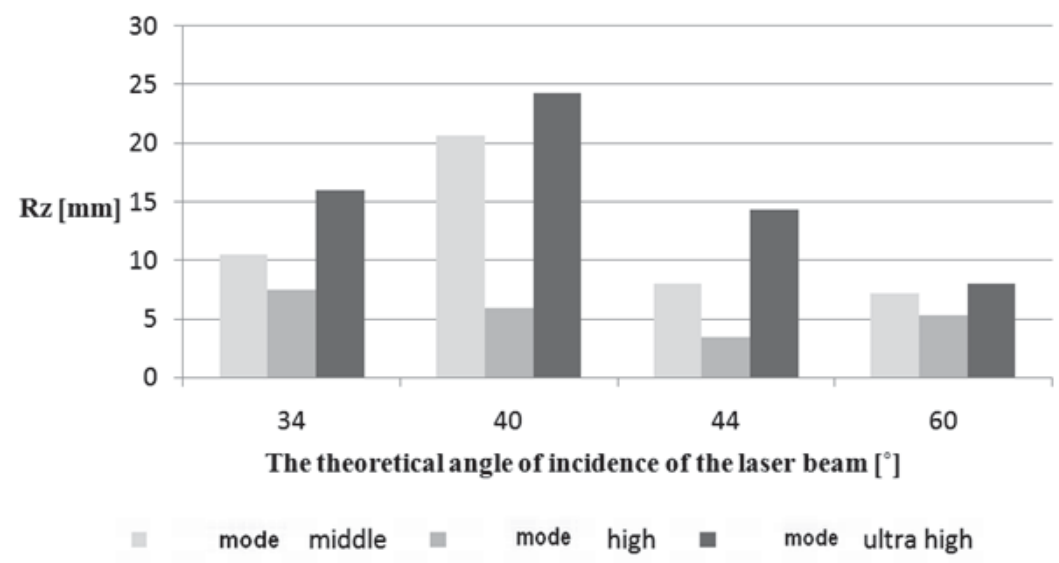

FIGURE 5. Graph presenting $R z$ parameter values for surface A of the concrete sample

presented in Table 3. The errors in the research paper were identified through analysis of the result comparison. For example, when determining the $R z$ parameter for an incidence angle of $40^{\circ}$ and high resolution (h) a point which was in fact a measurement noise was selected. The significant deviation of the $\sigma_{\max }$ parameter is evidence of this. Additional proof can be found in the sig- nificant deviation in other $R z$ parameter values for an incidence angle of $40^{\circ}$ and high resolution (h) determined for the same resolution but for different incidence angles. The $R z$ parameter is very sensitive to measurement errors that form so-called measurement peaks disrupting the obtained results. This can be observed by analysing the values in Table 2, where the obtained results 
TABLE 3. Summary of $\sigma_{\max }[\mathrm{mm}] \sigma_{\min }[\mathrm{mm}]$ $\sigma_{\text {all }}[\mathrm{mm}]$ values for surface A of the concrete sample (resolution m - "middle", h - "high", u - "ultra high")

\begin{tabular}{|c|c|c|c|c|}
\hline $\begin{array}{c}\text { Angle of } \\
\text { incidence } \\
\left({ }^{\circ}\right)\end{array}$ & $\begin{array}{c}\text { Reso- } \\
\text { lution }\end{array}$ & $\begin{array}{c}\sigma_{\max } \\
(\mathrm{mm})\end{array}$ & $\begin{array}{c}\sigma_{\min } \\
(\mathrm{mm})\end{array}$ & $\begin{array}{c}\sigma_{\text {all }} \\
(\mathrm{mm})\end{array}$ \\
\hline \multirow{3}{*}{34} & $\mathrm{~h}$ & 0.32 & 1.38 & 2.14 \\
\cline { 2 - 5 } & $\mathrm{m}$ & 0.54 & 1.22 & 4.02 \\
\cline { 2 - 5 } & $\mathrm{u}$ & 0.22 & 1.28 & 8.44 \\
\hline \multirow{4}{*}{40} & $\mathrm{~h}$ & 5.34 & 1.57 & 9.35 \\
\cline { 2 - 5 } & $\mathrm{m}$ & 0.52 & 1.35 & 3.29 \\
\cline { 2 - 5 } & $\mathrm{u}$ & 2.17 & 3.14 & 13.03 \\
\hline \multirow{4}{*}{44} & $\mathrm{~h}$ & 1.49 & 1.93 & 4.10 \\
\cline { 2 - 5 } & $\mathrm{m}$ & 0.26 & 0.83 & 1.91 \\
\cline { 2 - 5 } & $\mathrm{u}$ & 1.96 & 0.00 & 7.67 \\
\hline \multirow{3}{*}{60} & $\mathrm{~h}$ & 0.29 & 3.32 & 2.81 \\
\cline { 2 - 5 } & $\mathrm{m}$ & 0.33 & 0.19 & 2.80 \\
\cline { 2 - 5 } & $\mathrm{u}$ & 0.49 & 0.25 & 4.22 \\
\hline
\end{tabular}

Source: Kowalska and Zaczek-Peplinska 2015.

differ by $100 \%$. The data presented in Table 3 serves as confirmation of the low reliability of the $R z$ parameter determined using data form terrestrial laser scanning and that this method should not be used in order to determine surface roughness parameters.

The presented results are consistent with authors' previous experiments (Zaczek-Peplinska 2015) and subject literature (Kaasalainen 2011). They indicate a necessity to carry out analyses for smaller areas limited by the value of beam's incidence angle.

Using the results obtained from the earlier experiments one can assume the existence of different area classes with reference depending on the laser beam's incidence angle (Zaczek-Peplinska 2015):

- Class ID: scan distance up to $10 \mathrm{~m}$ $\cap$ angle of incidence $0-30^{\circ} \cap$ mode: High,

- Class IIDa: scan distance 10-50 m $\cap$ angle of incidence $0-40^{\circ} \cap$ mode: High,

- Class IIDb: scan distance do $30 \mathrm{~m} \cap$ angle of incidence $0-20^{\circ} \cap$ mode: Middle,

- Class IIDc: scan distance up to $20 \mathrm{~m} \cap$ angle of incidence $30-50^{\circ} \cap$ (mode: High $\cup$ Middle).

\section{Determining roughness parameters for inclined surfaces}

As previously mentioned, due to the specific character of engineering constructions, especially due to their complicated geometry, one cannot limit the possible orientations vertically oriented surfaces only. Thus, it is essential to analyse roughness parameters for planar surfaces oriented freely in the three-dimensional space. Because of that the orthogonal regression line which forms the average line should be replaced by a plane fit into a point cloud.

According to the definition of an average line, fitting of a plane into a point cloud has to be carried out using least squares method minimizing squared distance between the points and the surface. Fitting of the plane is performed through successive iterations. Output parameters for the plane are determined using three 
points - the centre of gravity of the point cloud and two most distant points from the said centre. During selection of the points their position is controlled in such a way that they have to be located on the opposite sides of the centre of gravity. The control involves determining the value of the angle between projections of straight lines that connect the selected points with the centre of gravity. The points are accepted if this angle is greater than $135^{\circ}$.

In order to perform the analysis a fragment of a scan of a flat, inclined concrete downstream wall of Rożnów dam was selected. The analysed surface covering the area of approximately $8 \times 50 \mathrm{~m}$ was marked on the scan's visualization using red colour (Fig. 6b). The scan was performed using scanning total station Leica Nova MS50 from the distance of approximately $50 \mathrm{~m}$. Inclination of the object's wall has no effect on the obtained results owing to the chosen methodology of determining $R a$ and $R z$ roughness parameters regarding to a surface iteratively fitted into point cloud being the result of the measurement. The influence of laser's angle of incidence on the surveyed surface is presented in Table 2 . This angle should be treated as a sum of the angle resulting from the position of the scanner and the surveyed wall's inclination angle.

Table 4 presents the determined values of $R a$ and $R z$ parameters for a section of a point cloud marked in Figure $6 \mathrm{~b}$ and for the three smaller areas designated from it (Fig. 7). Significant discrepancy of $R z$ parameter value results from the inclusion of protruding points which

TABLE 4. Summary of $R a$ and $R z$ parameter values calculated for the fragments marked in Figure 7 and the whole analysed area scanned using various resolution settings

\begin{tabular}{|l|c|c|}
\hline Description & $R a(\mathrm{~mm})$ & $R z(\mathrm{~mm})$ \\
\hline Area 1, resolution $2 \mathrm{~cm}$ & 6.00 & 56.00 \\
\hline Area 2, resolution 2 cm & 28.00 & 39.00 \\
\hline Area 3, resolution 2 cm & 23.00 & 150.00 \\
\hline Whole, resolution $2 \mathrm{~cm}$ & 13.00 & 201.00 \\
\hline Whole, resolution $5 \mathrm{~cm}$ & 13.00 & 252.00 \\
\hline Whole, resolution $15 \mathrm{~cm}$ & 14.00 & 247.00 \\
\hline
\end{tabular}

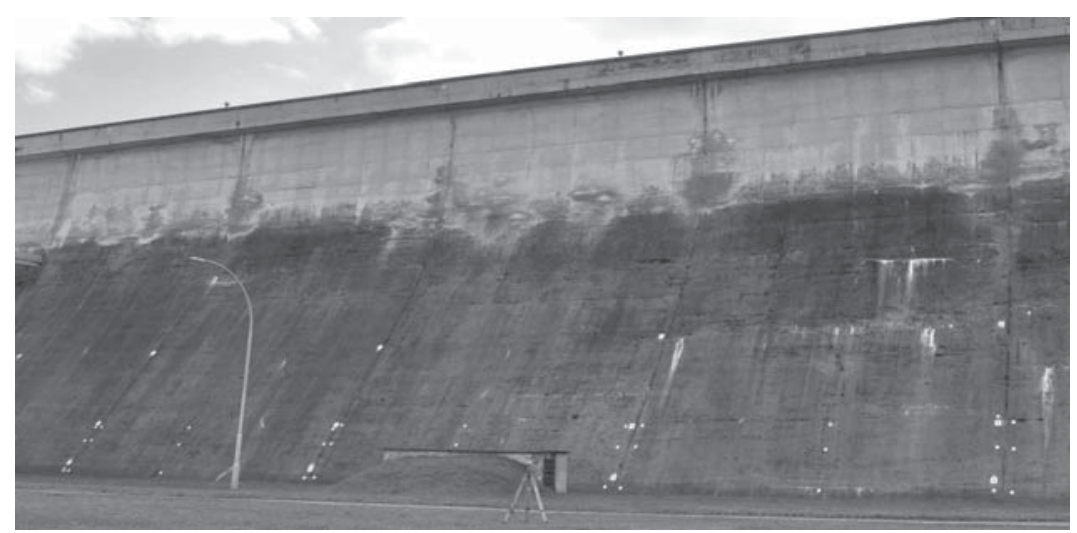

FIGURE 6a. A view of downstream wall of the water dam in Rożnów 


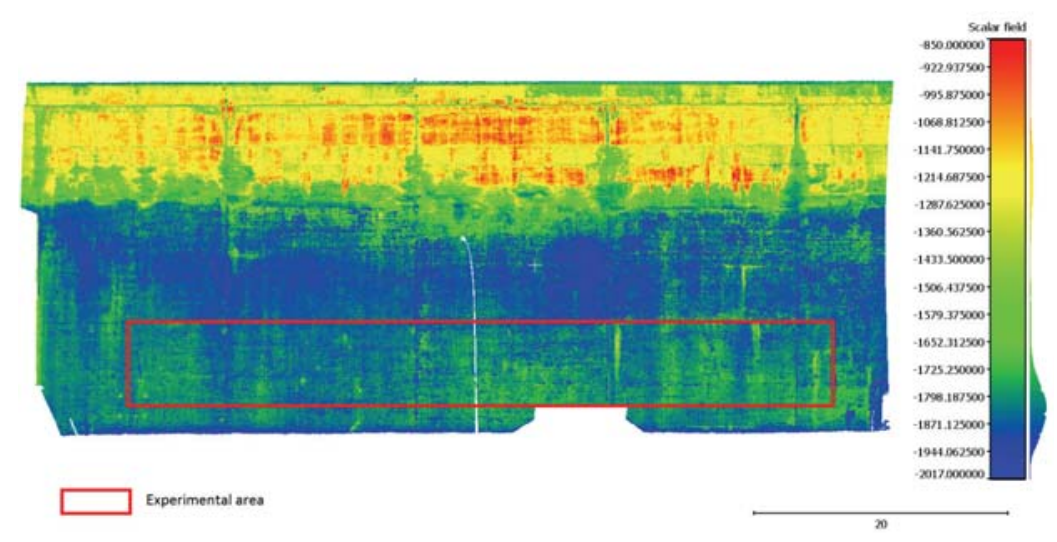

FIGURE 6b. Scan of the downstream wall of the water dam in Rożnów in intensity colouring with marked experimental area
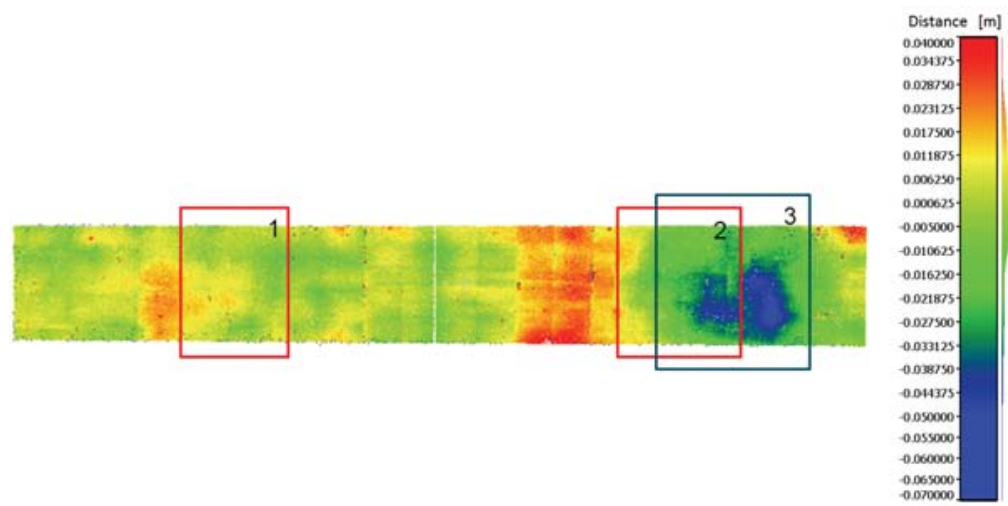

FIGURE 7. Map representing distances between points and the fitted average plane in colour range with marked test areas

interfere with the obtained value. The above-mentioned measurement peaks were marked in dark grey in Figure 7.

An analysis of the results summarised in Table 4 also shows that $R a$ parameter values for the whole experimental area are consistent regardless of the scan's resolution. However, it has to be emphasised that the resolution does not result from scanning mode but is the result of point selection based on the minimal dis- tance between the neighbouring points. Values of $R a$ and $R z$ are provided in millimetres due to the size of the expected changes.

\section{RESULTS AND DISCUSSION}

It is worth mentioning that when fitting a plane into a point cloud using least squares method, choosing the largest possible area of the point cloud provides the greatest advantages. However, when 
performing analysis of roughness parameters one should select significantly smaller areas. When analysing a large area, local surface unevennesses become averaged due to the characteristics of roughness parameters. This conclusion is supported by the results in Table 4 where average value of $R a$ parameter for areas 1 and $2-17 \mathrm{~mm}$ - is close to the parameter obtained on the basis of analysis of the whole area.

When determining roughness parameters based on the distances between the points from the average surface one also receives information on the object deformation. Figure 8 presents a juxtaposition image of the analysed area in the colour range of the reflected laser beam's intensity value, map visualising the distances between points and the fitted surface in colouring range and a photograph of the analysed experimental area.

The presented juxtaposition shows that when evaluating the condition of a surface one should base the assessment on information from various sources. General numerical characteristic of the surface is provided by the roughness parameter. Using this value as a base one can classify the type of treatment the surface should be subjected to. By analysing intensity values one obtains information on surface soiling (blue colour) or the occurring seepages (red colour). Map visualising the distances between points and the fitted surface can provide surface information on the possible deformations (cavities, protrusions). Photography allows for visual verification of the results.

Analysis of surface deformation, as in the case of roughness parameters, should be carried out for adequately sized areas. Figure 9 presents a juxtaposition of intensity image and deformation map for area 2 (Fig. 7) analysing a smaller area and choosing an individual colouring range provides better, and

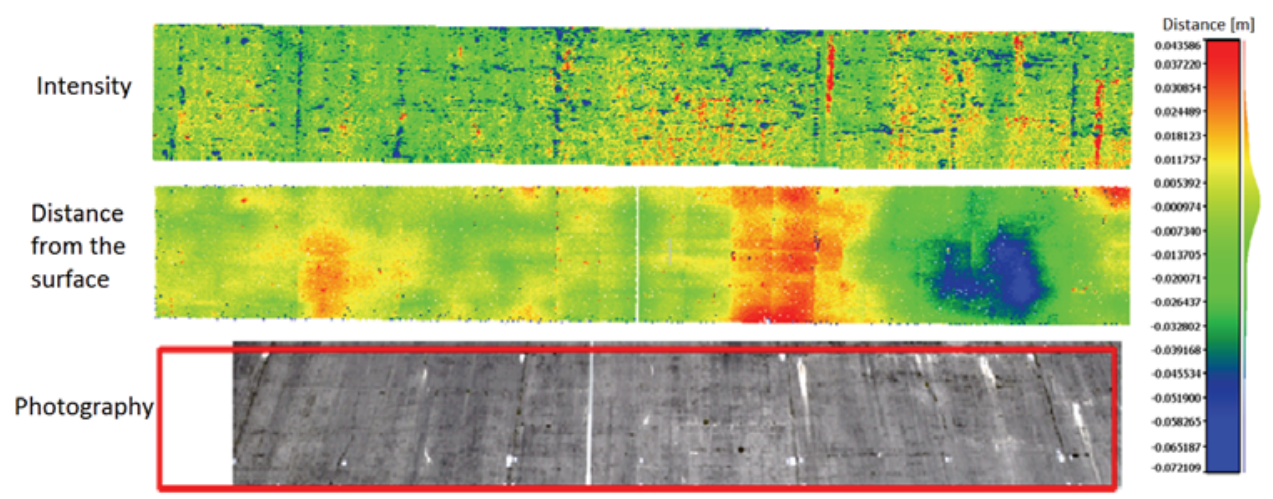

FIGURE 8. Juxtaposition of intensity image, map visualising the distances between points and the fitted surface presented in colouring range and a photography of the analysed test area 
as a result more detailed information on the selected area. When analysing the whole area it would be impossible to notice a crevice clearly visible in Figure 9.
$5-10 \mathrm{~mm}$ and larger, it is possible to ignore the noise present in the measurement "strip".

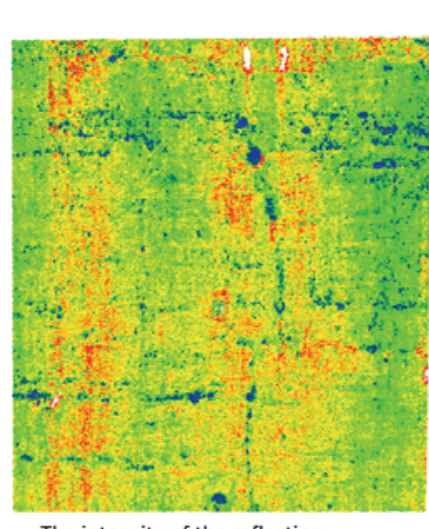

The intensity of the reflections
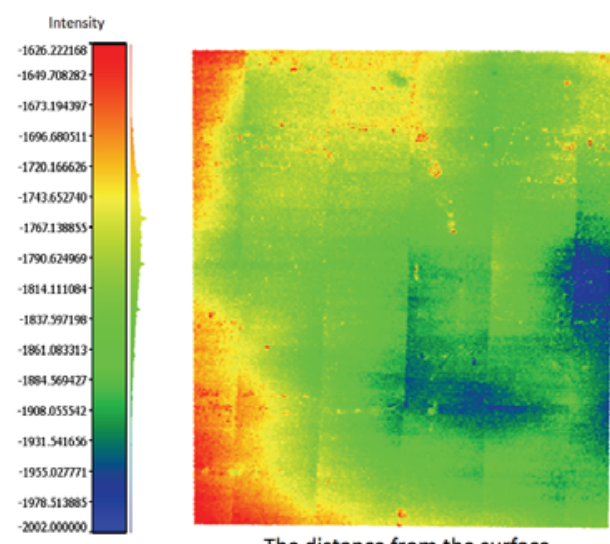

The distance from the surface

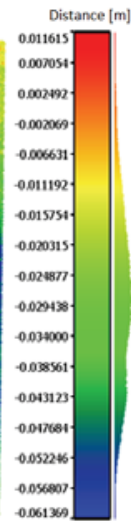

FIGURE 9. Juxtaposition of intensity image and the map visualising the distances between points and the fitted surface (test area 2)

Additionally, one can notice a cavity in its centre that is not visible on the intensity image.

When using data from terrestrial laser scanning in order to control the condition of concrete surfaces one has to bear in mind the "thickness" aspect of a point cloud. As a result of a scan of a selected section a "strip" is obtained which represents the structure of the surface. However, it also contains trace amounts of measurement noise. In view of the above, the approach suggested in the paper can be used to determine surface roughness on levels exceeding several millimetres and not on sub-millimeter level. Assuming the targeted changes and deformations fall within range of

\section{CONCLUSIONS}

Based on the previously mentioned results it may be concluded that the comparison of roughness parameters computed for an object after every periodic control measurement can constitute one evaluation element aiming at the assessment of the technical surface condition and indicate the stages of erosion of the concrete surface. Based on the change of roughness parameters in the following periods, the control measurements can be used to decide on the need for additional security activities like cleaning, coating the surface of safeguards, or carrying out repair processing - grinding, filling cavities. 
It is worth pointing out that the $R a$ parameter - mean distance value of the points on the observed profile from the average line on the sampling length - is "more resistant" to the changes in a scan resolution and the angle at which the surface is scanned than $R z$ parameter.

\section{REFERENCES}

CRAMÉR H. 1999: Mathematical methods of statistics. Vol. 9. Princeton University Press.

DOBRZYŃSKI T. 1977: Chropowatość i falistość powierzchni. Oznaczanie na rysunkach technicznych. Wydawnictwo Naukowo-Techniczne, Warszawa.

KAASALAINEN S., JAAKKOLA A., KAASALAINEN M. et al. 2011: Analysis of Incidence Angle and Distance Effects on Terrestrial Laser Scanner Intensity: Search for Correction Methods. Remote Sensing 3, 2207-2221. DOI:10.3390/rs3102207.

KOWALSKA M., ZACZEK-PEPLINSKA J. 2015: Wykorzystanie regresji ortogonalnej do analizy geometrii chmury punktów TLS. In: D. Dzięgielewski, D. Szychowski, J. Wernik (Eds). Wybrane problemy techniki. P.P.-H „Drukarnia” Sp. z o.o., Sierpc, 30-40.

SKUPNIK D., MARKIEWICZ E. 2013: Rysunek techniczny maszynowy i komputerowy zapis konstrukcji. Wydawnictwo Nauka i Technika, Warszawa.

ZACZEK-PEPLINSKA J., KOWALSKA M.E., NOWAK E. 2015: Selection of reference fields for statistical analysis of point clouds (TLS) in a process of technical condition assessment of concrete water dam. Conference book of International Conference On Civil and Environmental Engineering, ICOEE Cappadocia, Turcja, Newsehir 20-23.05.2015.
Streszczenie: Parametry chropowatości jako element oceny stanu powierzchni na podstawie $T L S$. Chropowatość jest to cecha powierzchni definiowana jako zbiór drobnych nierówności powierzchni, które nie wynikają z jej kształtu, a ich wielkość zależy od rodzaju materiału i przeprowadzonej obróbki. Najczęściej wykorzystywanymi parametrami chropowatości są: $R a$ - średnia wartość odległości punktów profilu zaobserwowanego od linii średniej na długości odcinka elementarnego, oraz $R z$ - różnica między średnią arytmetyczną wysokością pięciu najwyższych wzniesień i średnią arytmetyczną pięciu najgłębszych wgłębień względem linii średniej na długości odcinka pomiarowego. W praktyce najczęściej parametry chropowatości są określane dla powierzchni elementów, których odpowiednie wykonanie lub obróbka, np. szlifowanie, odlewanie czy polerowanie, ma zapewnić oczekiwaną chropowatość powierzchni. Do pomiaru tych parametrów dla zrealizowanych elementów wykorzystuje się profilometry. W artykule zaprezentowano odmienne podejście do wyznaczania i wykorzystania tych parametrów. Parametry chropowatości $\mathrm{w}$ tej pracy wyznaczane są na podstawie chmury punktów z naziemnego skaningu laserowego reprezentującej powierzchnię chropowatej próbki betonowej, a nie pomiaru odcinka elementarnego. Zaproponowano również wykorzystanie wyznaczonych w ten sposób parametrów chropowatości powierzchni jako danych uzupełniających w ocenie stanu (stopnia erozji) powierzchni konstrukcji z betonu.

\section{MS received November 2016}

\section{Authors' address:}

Janina Zaczek-Peplinska, Maria E. Kowalska Wydział Geodezji i Kartografii

Politechnika Warszawska

pl. Politechniki 1, pok. 304, 00-661 Warszawa

Poland

e-mail: jzaczek@gik.pw.edu.pl m.kowalska@gik.pw.edu.pl 